\title{
The effect of pasture manganese concentrations on lamb growth
}

\author{
L.C. SMITH ${ }^{1}$, K. KNOWLER ${ }^{1}$, J.D. MORTON ${ }^{2}$ and W.D. CATTO ${ }^{3}$ \\ ${ }^{1}$ AgResearch, Woodlands Research Station, RD 1, Invercargill \\ ${ }^{2}$ Ballance Agri-Nutrients, PO Box 65 Rolleston Canterbury \\ ${ }^{3}$ Ballance Agri-Nutrients, PB 12503, Mount Maunganui
}

chris.smith@agresearch.co.nz

\begin{abstract}
A trial was laid down at Woodlands in Southland to investigate the effect of pasture manganese (Mn) on sheep performance. Pasture Mn concentrations were increased from background concentrations $(82-98 \mathrm{mg} / \mathrm{kg} \mathrm{DM})$ to $192-354,466-694$ and $912-1178 \mathrm{mg} / \mathrm{kg} \mathrm{DM}$ by the regular spray application of $\mathrm{MnSO}_{4}$. These pasture concentrations were replicated four times and grazed by mobs of 10 Coopworth $\mathrm{x}$ Texel ram lambs. Pasture growth, botanical composition and pasture $\mathrm{Mn}$ concentrations were monitored. Lamb liveweights were measured fortnightly and the lambs were slaughtered after 14 weeks with the livers of six animals from each treatment sampled for vitamin $\mathrm{B}_{12}$, copper $(\mathrm{Cu})$, selenium (Se) and Mn concentration. Average clover content of the pastures declined throughout the trial, averaging $17 \%$, $15 \%$ and $4 \%$ for the three grazing areas respectively. Animal growth rates averaged $180 \mathrm{~g} /$ day for the duration of the experiment but varied from $250 \mathrm{~g}$ /day during the first 2 weeks they grazed the pastures declining steadily for each 2 week period they remained on that group of paddocks to a low of $<90 \mathrm{~g}$ /day after 6 weeks. The animal growth rates were only significantly influenced by extremely high initial Mn concentrations ( $>2000 \mathrm{mg}$ / $\mathrm{kg} \mathrm{DM}$ ) or where concentrations were above $1200 \mathrm{mg}$ / $\mathrm{kg}$ DM for the full 2 week grazing period. There was no effect of high $\mathrm{Mn}$ intake on liver $\mathrm{B}_{12}, \mathrm{Se}, \mathrm{Cu}$ or $\mathrm{Mn}$ under these conditions.
\end{abstract}

Keywords: sheep, manganese, lamb growth rates, pasture manganese concentration

\section{Introduction}

Manganese (Mn) concentrations in New Zealand pastures are generally not considered to be high enough to adversely influence pasture production (Smith \& Edmeades 1983). However increased herbage Mn concentrations may affect animal performance since Grace (1973) found that sheep fed pellets with Mn concentrations in excess of $400 \mathrm{mg} / \mathrm{kg}$ dry matter (DM) had their daily weight gains decreased by about $40 \%$. This is in contrast to overseas researchers who have reported no decrease in animal growth rates until pasture Mn concentrations exceeded $2000 \mathrm{mg} / \mathrm{kg} \mathrm{DM}$ (Cunningham et al. 1966; Ivan \& Hidiroglou 1980; Black et al. 1985a; Paynter 1987). However there is little information on whether this decrease in weight gain is gradual as Mn concentration increases.

While concentrations as high as the $400 \mathrm{mg} / \mathrm{kg}$ DM threshold reported by Grace (1973) are not common in New Zealand, they can be found in parts of Central Otago (Smith et al. 2004). The pasture concentration of Mn fluctuates during the year, with concentrations reported as being highest in the winter (May-August, Smith et al. 2004) or late summer period (January-March, Metson et al. 1979). For the former period, breeding stock could be adversely affected by high $\mathrm{Mn}$, while for the latter period growth rates of weaned lambs would be affected.

The study reported here was initiated to assess the concentration at which $\mathrm{Mn}$ induced changes in animal growth rates, and the pattern of these changes.

\section{Methods}

\section{Trial site and design}

The trial was located on a Woodlands silt loam (mottled firm brown soil; Hewitt 1998) at the Woodlands Research Station in Southland. Two groups of four paddocks with similar histories in terms of fertiliser application were selected for their evenness of size and pasture cover. Paddock sizes ranged from 1.10 to 1.18 ha in the first group and from 1.19 ha to 1.25 ha in the second. Each of the four paddocks was subdivided into four equal subpaddocks by means of temporary netting fences with treatments allocated to the sub-paddocks using a randomised block design, modified so that no treatment was favoured by being near shelter or laneways. Treatments containing different pasture $\mathrm{Mn}$ concentrations (Mn treatments 1, 2,3 and 4) were created by the spray application of $0,2.5,7.5$ and $15 \mathrm{~kg} \mathrm{Mn} / \mathrm{ha}$ as manganese sulphate $\left(\mathrm{MnSO}_{4}\right)$ in 300 litres water/ha respectively. These rates were calculated from a small plot trial to give herbage concentrations ranging from the background level of $82-98 \mathrm{mg} / \mathrm{kg}$ DM to $800-1000 \mathrm{mg} /$ $\mathrm{kg}$ DM. Manganese was initially applied to the appropriate sub-paddocks in the first group on 28 January 2005,3 days prior to the animals being placed on the appropriate treatments. The Mn treatments were reapplied every 2 weeks to maintain the appropriate herbage Mn concentrations.

Mn was applied to the second group of paddocks on 11 February, again 3 days prior to the animals being 
introduced. Following the Mn application on 10 March 2005, it was discovered that the Mn concentration in the herbage had not increased to the extent required. Hence the 7.5 and $15 \mathrm{~kg} / \mathrm{ha}$ rates were re-applied on 11 March Following a 6 week grazing period of the second group of paddocks, Mn was reapplied to the first group of paddocks on 22 March, 2 days prior to the animals being re-introduced to that group of paddocks.

\section{Animals and measurements}

On 31 January 2005, 160 ram lambs (3/4 Coopworth - 1/4 Texel born September 2004) were weighed and randomly separated into 16 mobs of 10 animals per mob. The mobs were then randomly allocated and placed on to the 16 sub-paddocks of the grazing area. The animals were weighed every 2 weeks, and placed back in their appropriate paddocks, until the trial was completed.

Initial intentions were to set stock and graze each of the two groups of paddocks for 6 weeks. However due to the high pasture mass at the start of the trial $(3900 \mathrm{~kg}$ $\mathrm{DM} / \mathrm{ha}$ ) and the rapid pasture growth experienced at that time causing pasture quality concerns, the animals were removed from the first group of paddocks after 2 weeks (= grazing period 1 ) and shifted to the identically randomised and treated paddocks in the second group where the pasture mass was less ( $2400 \mathrm{~kg} \mathrm{DM} / \mathrm{ha})$ and the quality higher. Following a 6 week grazing period (grazing period 2) for the second group of paddocks, the animals were returned to the first group for the final 4 weeks of the experiment. This group of paddocks had been grazed with a mob of ewes following the first grazing period, so that pasture mass for the final grazing period (grazing period 3) was similar to that of the second group of paddocks (2600-2800 kg DM/ha).

To prevent the animals from grazing the $\mathrm{MnSO}_{4}$ salt directly, all animals were removed from the trial area for 24 hours at each re-application of the Mn treatments and held in laneways. An exception was made for the reapplication of the two high Mn rates on 11 March 2005 due to rain falling at the time and the fact that the animals had just been placed on these trial paddocks.

Prior to animals commencing the grazing of these areas, and weekly, while the animals were grazing, pasture samples were collected across a set transect of each subpaddock. These samples were divided, with one half being dried at $65^{\circ} \mathrm{C}$ and analysed for $\mathrm{Mn}\left(\mathrm{HNO}_{3} / \mathrm{HClO}_{4}\right.$ digestion; ICP-OES determination, Boumans 1980) and Fe (Nitric perchloric digest; Martinie \& Schilt 1976). The other half of the herbage samples was separated into grass, clover, weeds and dead material. Additionally, on several occasions immediately following treatment application, the herbage sample was sub-divided, with one sample from each paddock washed prior to drying, so as to measure the pasture uptake of the sprayed $\mathrm{MnSO}_{4}$. The herbage samples collected from the first group of paddocks on 24 March were further subdivided with one portion separated into grass and clover for $\mathrm{Mn}$ analysis, while similar grass samples collected on 7 April were separated into leaf and stem prior to drying and analysing for Mn concentration.

Pasture mass was measured both pre grazing and at the completion of grazing across the same transect by means of a rising plate meter (Thomson et al. 2001).

Following the completion of the trial the animals were sent for slaughter, with liver samples collected from six randomly selected animals within each treatment. These samples were analysed via OPTIGRO trace element protocols for $\mathrm{B}_{12}, \mathrm{Se}, \mathrm{Cu}$ and $\mathrm{Mn}$.

All procedures involving the experimental use of sheep were approved by the Crown Research Institutes' Animal Ethics Committee (Approval no. INV10415; Invermay, Mosgiel, New Zealand)

\section{Statistical analysis}

All statistical analysis was done by ANOVA within GenStat v 8.11. For the animal growth rates the block structure was given by mob, and treatment structure given by Mn level applied. To assess patterns of change over time, difference contrasts between post- and pre-treatment data were analysed by ANOVA as above.

\section{Results}

\section{Herbage Mn concentrations}

Initially there was a slight decline in herbage $\mathrm{Mn}$ concentrations for the first group of paddocks in the weeks between spraying (Fig. 1A). Base herbage Mn concentration averaged $82 \mathrm{mg} / \mathrm{kg}$ DM for both grazing periods 1 and 3 , with the treated sub-paddocks averaging 234-354, 466-692 and 1006-1178 $\mathrm{mg} / \mathrm{kg} \mathrm{DM}$ for the three rates of Mn treatments (Fig. 1A). There was little increase in the Mn concentrations for the second group of paddocks until after the re-application of the two high Mn rates with a large increase occurring at these rates on 13 and 21 March (Fig. 1B). This increase meant that the average herbage $\mathrm{Mn}$ concentrations for this group were $98,192,499$ and $912 \mathrm{mg} / \mathrm{kg}$ DM for the four treatments. Prior to the double application, the concentrations only averaged 97, 208, 271 and $466 \mathrm{mg} / \mathrm{kg} \mathrm{DM}$ for treatments 1 to 4 respectively.

Washing the samples, collected following Mn application, significantly reduced the herbage Fe concentrations on two occasions but had no effect on the herbage Mn concentrations (Table 1). This indicates that at least $90 \%$ of the Mn had been absorbed into the plant during the $24 \mathrm{~h}$ that animals were removed following treatment reapplication.

There was no effect of botanical fraction on herbage 
Figure 1 Herbage Mn concentrations over the duration of the trial for (A) area 1, grazing periods 1 and 3, (B) area 2 grazing period 2. $\Delta$ indicates when $\mathrm{MnSO}_{4}$ was applied. Bars are $\mathrm{LSD}_{0.05}$.
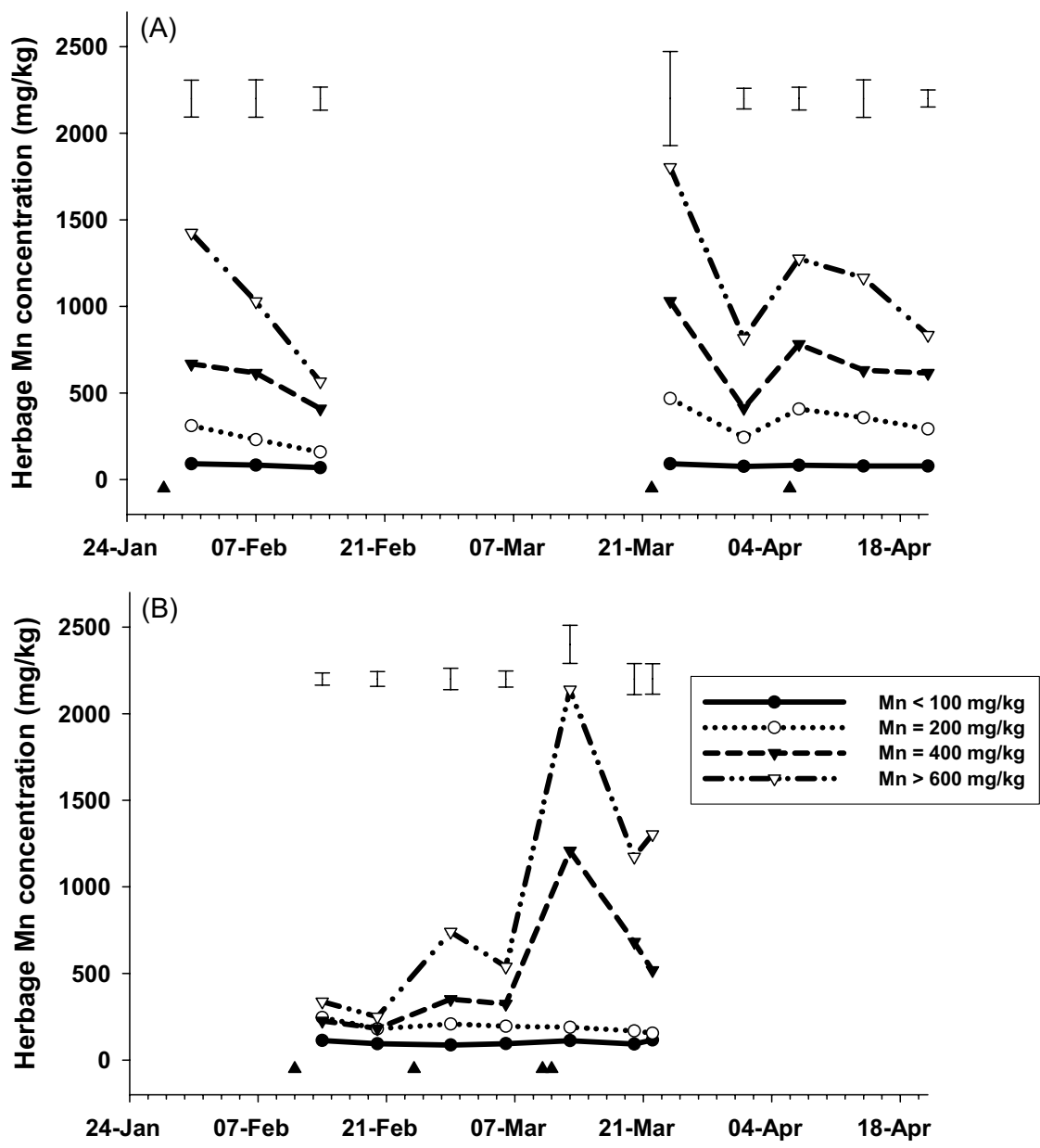

Table 1 Effect of washing on herbage $\mathrm{Mn}$ and Fe concentrations (mg/kg DM).

\begin{tabular}{|c|c|c|c|c|c|c|}
\hline \multirow[t]{2}{*}{$\begin{array}{l}\text { Date sampled } \\
\text { Days since } M n \text { application }\end{array}$} & \multicolumn{2}{|c|}{$\begin{array}{l}31 \text { Jan } \\
3 \text { days }\end{array}$} & \multicolumn{2}{|c|}{$\begin{array}{l}14 \text { Feb } \\
3 \text { days }\end{array}$} & \multicolumn{2}{|c|}{$\begin{array}{l}7 \text { April } \\
1 \text { day }\end{array}$} \\
\hline & $\mathrm{Fe}$ & $\mathrm{Mn}$ & $\mathrm{Fe}$ & $\mathrm{Mn}$ & $\mathrm{Fe}$ & $\mathrm{Mn}$ \\
\hline $\begin{array}{l}\text { Unwashed } \\
\text { Washed } \\
\text { LSD }_{0.05}\end{array}$ & $\begin{array}{c}126 \\
82 \\
13^{\star \star *}\end{array}$ & $\begin{array}{l}624 \\
545 \\
92^{\mathrm{NS}}\end{array}$ & $\begin{array}{l}137 \\
122 \\
24^{\mathrm{NS}}\end{array}$ & $\begin{array}{l}231 \\
227 \\
49^{\text {NS }}\end{array}$ & $\begin{array}{r}182 \\
112 \\
22^{\star \star \star}\end{array}$ & $\begin{array}{l}637 \\
642 \\
79^{\text {NS }}\end{array}$ \\
\hline Treat $\times$ Washing & NS & NS & NS & NS & NS & NS \\
\hline
\end{tabular}

Significance; NS = not significant, ${ }^{* * *}=P<0.001$

Mn concentrations (Table 2) despite clover concentrations being lower in the control areas and higher in the treated areas. The grass leaves had significantly higher Mn concentrations than the green grass stems $(\mathrm{P}<0.001$; Table 2$)$.

\section{Pasture botannical composition}

The average clover content for the grazing periods was
$17 \%, 15 \%$ and $4 \%$ for the three grazing periods respectively. The clover content of the pasture declined rapidly in the first grazing period from $34 \%$ initially to $10 \% 1$ week later. For the second group of paddocks the clover content dropped from $25 \%$ initially to $18 \%$ after 1 week, and then declined by $2 \%$ per week. For the grazing period 3 the clover content was similar for the whole 4 week duration. 
Table 2 Herbage Mn concentrations ( $\mathrm{mg} / \mathrm{kg} \mathrm{DM}$ ) at different rates of $\mathrm{Mn}$ application for grass and clover and for different components of grass.

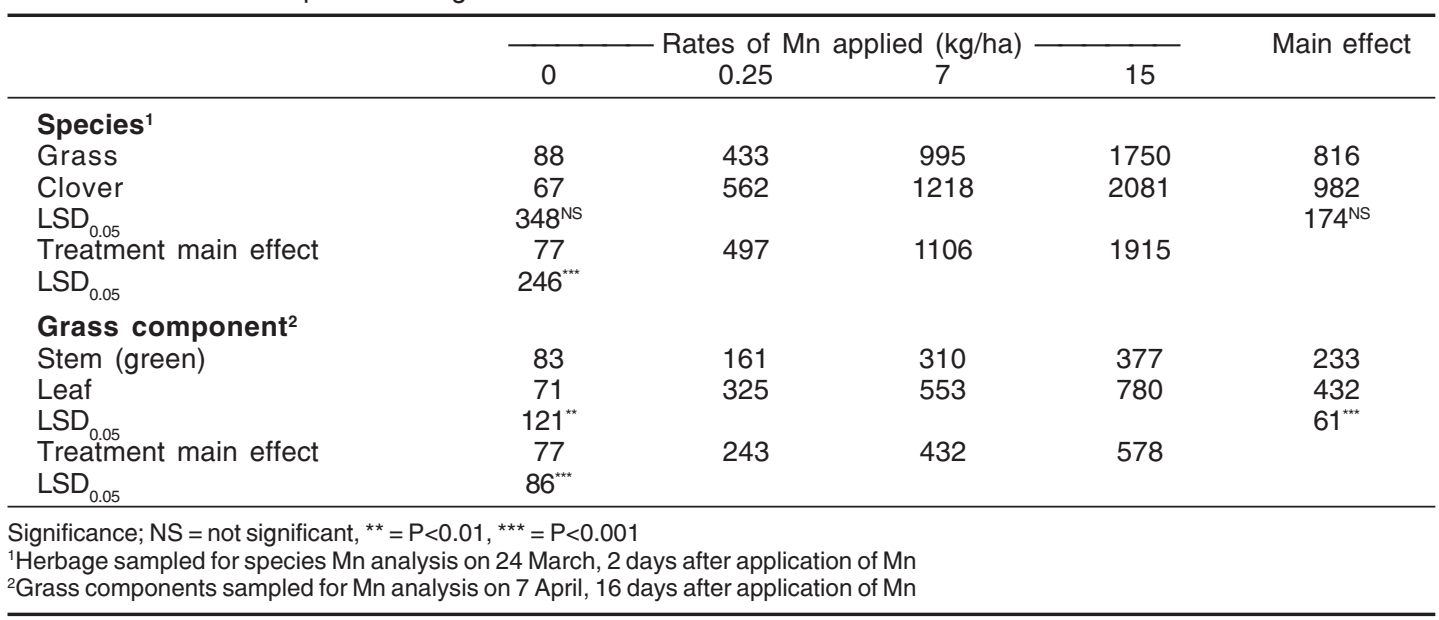

Table 3 Daily animal growth rates for three grazing periods over the duration of the trial ( $g /$ day)

\begin{tabular}{|c|c|c|c|c|c|c|}
\hline \multirow{2}{*}{$\begin{array}{l}\text { Rate of } \\
\mathrm{Mn} \\
(\mathrm{kg} / \mathrm{ha})\end{array}$} & \multicolumn{2}{|c|}{ Period 1} & \multicolumn{2}{|c|}{ Period 2} & \multicolumn{2}{|c|}{ Period 3} \\
\hline & $\begin{array}{c}31 \mathrm{Jan}- \\
14 \mathrm{Feb}\end{array}$ & $\begin{array}{l}14 \text { Feb - } \\
24 \text { Feb }\end{array}$ & $\begin{array}{c}\text { 24-Feb - } \\
10 \text { Mar }\end{array}$ & $\begin{array}{l}10 \text { Mar - } \\
24 \text { Mar }\end{array}$ & $\begin{array}{c}24 \mathrm{Mar} \text { - } \\
6 \mathrm{Apr}\end{array}$ & $\begin{array}{l}6 \mathrm{Apr}- \\
22 \mathrm{Apr}\end{array}$ \\
\hline 0 & 220 & 260 & 151 & 93 & 219 & 113 \\
\hline 2.5 & 194 & 248 & 161 & 72 & 256 & 100 \\
\hline 7 & 203 & 287 & 100 & 72 & 246 & 118 \\
\hline 15 & 235 & 239 & 143 & 29 & 247 & 117 \\
\hline LSD $_{0.05}$ & $44^{\mathrm{NS}}$ & $66^{\mathrm{NS}}$ & $66^{\mathrm{NS}}$ & $32^{* *}$ & $57^{\mathrm{NS}}$ & $43^{\mathrm{NS}}$ \\
\hline
\end{tabular}

Significance NS = not significant; ${ }^{* *}=\mathrm{P}<0.01$.

\section{Pasture yield and animal intakes}

Pre-grazing pasture mass averaged 3900, 2400 and 2700 $\mathrm{kg} \mathrm{DM} /$ ha for the three grazing periods. These figures and the post-grazing pasture mass were used, together with the pasture growth rate, as measured at Woodlands Research Station using the moving cage technique (Radcliffe 1974), to calculate animal pasture intakes. These intakes were 2.0, 3.0 and $1.6 \mathrm{~kg} \mathrm{DM} /$ animal/day for the grazing periods 1 - 3 respectively. Intakes were similar for all mobs of animals within each grazing period irrespective of Mn concentration (data not shown).

\section{Animal liveweights}

Animal growth rates were highest during the first 2 weeks the animals grazed the pastures and declined steadily for each 2 week period they remained on that group of paddocks (Table 3). For only one measurement period, 10 March to 24 March, were there significant differences in daily growth rates as a consequence of treatment (Table 3; $\mathrm{P}<0.01$ ). It was only at the highest Mn concentration $(>1200 \mathrm{mg} / \mathrm{kg}$ ) in the herbage (Figure 1B; $12-24$ March) that a significant drop in animal growth rate was measured. There was no difference between the other treatments measured.

\section{Liver vitamin $B_{12}$ and mineral concentrations}

The concentrations of vitamin $\mathrm{B}_{12}, \mathrm{Se}, \mathrm{Cu}$ and $\mathrm{Mn}$ in the livers sampled were all within the ranges considered adequate for animal health and showed no significant effects of treatment (Table 4).

\section{Discussion}

High pasture Mn is known to cause decreases in animal growth rates (Cunningham et al. 1966; Grace 1973; Ivan \& Hidiroglou 1980; Black et al. 1985a; Paynter 1987). However there is some debate as to the concentration at which this decrease occurs. Our study indicates that significant depressions in animal growth rates only occur at extremely high initial Mn concentrations ( $>2000 \mathrm{mg}$ / $\mathrm{kg} \mathrm{DM}$ ) or where concentrations were above $1200 \mathrm{mg} /$ $\mathrm{kg}$ DM for the full 2 week grazing period (Fig. 1B; $13-$ 24 March). This threshold is somewhat higher than that reported by Grace (1973), but is similar to or lower than that reported by other workers (Cunningham et al. 1966; Ivan \& Hidiroglou 1980; Black et al. 1985a; Paynter 1987). The differences in sheep growth rate responses to $\mathrm{Mn}$ intakes observed in the various trials (e.g. the high pasture Mn concentrations in this study cf. the study of Grace (1973)) is likely to be due to form of Mn in the 
Table 4 Effect of herbage Mn treatment on liver vitamin $\mathrm{B}_{12}$, Se $\mathrm{Cu}$ and $\mathrm{Mn}$ concentrations.

\begin{tabular}{|c|c|c|c|c|}
\hline $\begin{array}{l}\text { Mn rate } \\
(\mathrm{kg} / \mathrm{ha}) \\
\quad \text { Adequate range }\end{array}$ & $\begin{array}{l}\text { Vitamin B12 } \\
(\mathrm{nmol} / \mathrm{kg}) \\
>375\end{array}$ & $\begin{array}{c}\mathrm{Se} \\
(\mathrm{nmol} / \mathrm{kg}) \\
>450\end{array}$ & $\begin{array}{c}\mathrm{Cu} \\
(\mu \mathrm{mol} / \mathrm{kg}) \\
>95\end{array}$ & $\begin{array}{c}\mathrm{Mn} \\
(\mu \mathrm{mol} / \mathrm{kg}) \\
37-81\end{array}$ \\
\hline $\begin{array}{l}0 \\
2.5 \\
7 \\
15\end{array}$ & $\begin{array}{l}543 \\
510 \\
642 \\
578\end{array}$ & $\begin{array}{l}2575 \\
3102 \\
2948 \\
2967\end{array}$ & $\begin{array}{l}1840 \\
1720 \\
2572 \\
2005\end{array}$ & $\begin{array}{l}38 \\
40 \\
38 \\
46\end{array}$ \\
\hline LSD $_{0.05}$ & $183^{\text {NS }}$ & $553^{\mathrm{NS}}$ & $772^{\text {NS }}$ & $10^{\mathrm{NS}}$ \\
\hline
\end{tabular}

Significance; NS = not significant

${ }^{1}$ (Morton et al. 1999)

diet. This is in agreement with the findings of Paynter (1987) who suggested that method of $\mathrm{Mn}$ supplementation was the key factor, and that daily oral dosing with Mn was not equivalent to Mn supplied in feed. Grace (1973) also suggested that high levels of dietary Mn can reduce feed intake. While this has been observed in other studies, Black et al. (1985b) found that it was animals dosed by capsules that consumed less feed and not those where Mn was administered in the diet. There was no apparent change in feed intake due to $\mathrm{Mn}$ concentration in our study even with $\mathrm{Mn}$ concentrations up to $1500 \mathrm{mg} / \mathrm{kg}$ and hence we concur with this finding.

The period where we measured a significant decline in animal growth rates at the highest pasture $\mathrm{Mn}$ concentration, also coincided with the period of lowest animal growth for the whole duration of the trial $(<100$ $\mathrm{g} /$ day; Table 3). The likely reason for the drop in overall animal growth with time was a drop off in pasture availability and quality with length of time that animals were set stocked on the pasture. Hence the implication is that pasture quality had a greater influence on animal growth rates than Mn concentration in this situation.

In contrast to other studies (Black et al. 1985b; Grace 1973; Ivan \& Hidiroglou 1980; Paynter 1987), we found no measurable effect of high Mn intake on liver Mn concentrations. This may be in part due to the form of $\mathrm{Mn}$, as all the other studies had Mn supplemented as pellets or directly mixed in various forms to the feed, and not naturally absorbed in the feed as in this study. In addition, with the exception of Grace (1973) and Paynter (1987), Mn supplementation rates were considerably higher than those of this study.

These results show that on high quality pastures where herbage $\mathrm{Mn}$ concentrations tend to be relatively low (<250 mg/kg: AgResearch 1994), that herbage Mn is not a problem for grazing animals. Where these results may have implications, is in those areas, such as Central Otago, where pasture Mn can be high ( $>500 \mathrm{mg} / \mathrm{kg})$. As this study indicated that pasture quality had a greater effect than Mn concentration, it is likely factors such as pasture quality could also be influencing animal performance in these areas, where these high Mn concentrations tend to coincide with poor quality browntop dominant pastures (Smith et al. 2004). The results of this study re-inforce the premise suggested earlier (Smith et al. 2004) that high pasture Mn could be less of a problem if pasture quality in these areas was improved.

\section{ACKNOWLEDGEMENTS}

We wish to thank Crystel Howden for collecting the pasture samples, Nigel Wood, Megan Collins and Roger Wheeler for the animal management and measurements and Roger Littlejohn for statistical advice. This work was funded by Ballance Agri-Nutrients.

\section{REFERENCES}

AgResearch 1994. Trace element status of Southland and South Otago sheep farms. A research report prepared for Southfert. $79 \mathrm{pp}$.

Black. J.R.; Ammerman, C.B.; Henry, P.R. 1985a. Effects of high dietary manganese as manganese oxide or manganese carbonate on sheep. Journal of Animal Science 60: 861-866.

Black. J.R.; Ammerman, C.B.; Henry, P.R. 1985b. Effect of quantity and route of administration of manganese monoxide on feed intake and serum manganese in ruminants. Journal of Dairy Science 68: 433-436.

Boumans, P. 1980. Line Coincidence for ICPAES Spectroscopy, (Volumes 1 and 2). Pergamon Press, Oxford, England.

Cunningham, G.N.; Wise, M.B.; Barrick, E.R. 1966. Effect of high dietary levels of manganese on the performance and blood constituents of calves. Journal of Animal Science 25: 532-538.

Grace, N.D. 1973. Effect of high dietary Mn levels on the growth rate and the level of mineral elements in the plasma and soft tissues of sheep. New Zealand Journal of Agricultural Research 16: 177-180.

Hewitt, A.E. 1998. New Zealand Soil Classification. Landcare Research science series 1. Manaaki Whenua Press, Lincoln, Canterbury.

Ivan, M.; Hidiroglou, M. 1980. Effect of dietary 
manganese on growth and manganese metabolism in sheep. Journal of Dairy Science 63: 385-390.

Martinie, G.D., Schilt, A.A. 1976. Investigation of the wet oxidation efficiencies of perchloric acid mixtures for various organic substances and the identities of residual matter. Analytical Chemistry 48: 70-74.

Metson, A.J.; Gibson, E. Janice; Hunt, J.L.; Saunders, W.M. H. 1979. Seasonal variations in chemical composition of pasture. III. Silicon, aluminium, iron, zinc, copper and manganese. New Zealand Journal of Agricultural Research 22: 309-318.

Morton, J.D.; Grace, N.D.; O'Connor, M.B. 1999. Use of trace elements in New Zealand pastoral farming. New Zealand Fertilisers Manufacturers' Research Association. Newmarket, Auckland.

Paynter D.I. 1987. Effects of high dietary manganese of body and wool growth in sheep. Pp. 390-392. In: Temperate pastures: their production, use and management. Eds Wheeler, J.L.; Pearson, C.J.; Robards, G.E.: C.S.I.R.O. Victoria. Australia.
Radcliffe, J.E. 1974. Seasonal distribution of pasture production in New Zealand I. Methods of measurement. New Zealand Journal of Experimental Agriculture 2: 337-340.

Smith, G. S.; Edmeades, D. C. 1983. Manganese status of New Zealand pastures. 2. Pasture concentrations. New Zealand Journal of Agricultural Research 26: 223-225.

Smith, L. C.; Trainor, K.D.; Catto, W.D. 2004. The use of lime to alleviate high pasture manganese in Central Otago. Proceedings of the New Zealand Grassland Association 66: 49-55.

Thomson, N.A.; Upsdell, M.P.; Hooper, R.; Henderson, H.V.; Blackwell, M.B.; McCallum, D.A.; Hainsworth, R.J.; MacDonald, K.A.; Wildermoth, D.D.; BishopHurley, G.J.; Penno, J.W. 2001. Development and evaluation of a standardised means for estimating herbage mass of dairy pastures using a rising plate meter. Proceedings of the New Zealand Grassland Association 63: 149-157. 